\title{
MATEMÁTICA VERSUS LÍNGUA PORTUGUESA: O ÂNGULO AGUDO DE UMA RELAÇÃO ÍMPAR
}

\author{
Mariza Rosâni Abreu da SILVEIRA \\ Programa de Pós-graduação em Ciências e Matemática/UFPA \\ marisabreu@ufpa.br \\ Ronaldo RIPARDO \\ Programa de Pós-graduação em Ciências e Matemática/UFPA \\ ripardo22@yahoo.com.br
}

Resumo: Neste artigo procuramos mostrar que a Matemática e a Língua Portuguesa não são disciplinas opostas e alguns aspectos do fenômeno que aponta como Lingua e Matemática se aproximam, ao invés de se distanciarem. A discussão está assentada nos referenciais teóricos de Ludwig Wittgenstein, Paul Ricouer, Nilson José Machado e Gilles Gaston-Granger, permeada por outros autores que discutem a temática.

Palavras-chave: Linguagem Matemática. Lingua Materna. Metáfora. Sistemas de representação.

Abstract: In this article we seek to show that Mathematics and Portuguese Language are not opposite disciplines and some aspects of the phenomenon which indicates how language and Mathematics approach each other, rather than being apart. The discussion is based on the theoretical references of Ludwig Wittgenstein, Paul Ricouer, Nilson José Machado and Gilles Gaston-Granger, together with other authors who discuss this theme.

Keywords: Mathematical Language. Mother Language. Metaphor. Systems of representation.

\section{Introdução}

Matemática e Língua Portuguesa são consideradas por alunos, ou por aqueles que já frequentaram a escola, duas áreas do conhecimento completamente antagônicas, quer sejam pelas características sobrelevadas no ensino dessas disciplinas no currículo escolar quer sejam pelos usos que se fazem delas nos mais diversos contextos sociais. Aliás, quando este último fator se concretiza é motivo para professores sentirem-se bem 
mais aliviados, haja vista estarem convivendo sempre com comentários como "Não sei para que estudar tanto matemática [ou português] se lá fora nunca uso isso".

Evidentemente, longe dos muros das escolas e das paredes das salas de aula, dificilmente verifica-se alguém apontando limites sólidos demarcando o que pertence à Língua Portuguesa e o que pertence à Matemática. Também são raras dentro do espaço escolar quaisquer tentativas, por mais ousadas que sejam, de aproximação entre essas duas disciplinas. Ou seja, se longe do espaço escolar as duas estão unidas, entrelaçadas, no ambiente escolar as duas são palco latente de uma permanente e sempre viva dicotomia, principalmente didática.

A propósito, poderia alguém imaginar, por mais improvável que seja a ideia, a possibilidade de a capacidade de aprender Matemática ser a mesma necessária para um indivíduo falar uma língua? Há de se concordar que parece ser esta uma ideia absurda, improvável. Mas, segundo Devlin (2004), a capacidade de aprender matemática é, do mesmo modo que a faculdade humana para a linguagem, inata e qualquer pessoa que fale e compreenda bem sua língua materna é capaz de aprender Matemática e vice-versa. De acordo com essa teoria "[...] as características do cérebro que nos permitem lidar com a matemática são aquelas mesmas que nos permitem usar a linguagem - falar com os outros e entender o que eles dizem" (p. 20).

Outro viés dessa relação é apontado por Granger, ao afirmar que "[...] las lenguas más o menos formalizadas de la ciencia, aunque profundamente distintas de las lenguas vernáculas, no dejan de conservar algunos rasgos esenciales de estas últimas" (1995, p. 88). Ou seja, a Matemática conserva as características da língua materna de quem a utiliza, no nosso caso, a Língua Portuguesa. Esse aspecto da relação se evidencia por causa de uma característica da linguagem matemática que será discutida mais adiante.

A ideia de conceber Matemática e Língua Portuguesa como disciplinas em estreita relação pode romper com certos paradigmas. Um deles diz respeito ao seu uso como instrumento de dominação e poder que se fazem presentes desde o início da história da humanidade. $\mathrm{Na}$ Antiguidade, por exemplo, a oratória e a Matemática (aritmética e geometria) eram tidas como ferramentas necessárias para alcançar-se um 
estado supremo de conhecimento. Atualmente estas mesmas componentes são usadas como mecanismos de seleção para os "mais inteligentes" - as provas de concurso e do vestibular são um bom exemplo disso. A vida escolar de muitos alunos poderia ser bem menos conflituosa e bem mais exitosa se não houvesse tantos juízos de valor a respeito da natureza epistemológica tanto da Matemática como da Língua Portuguesa dentro da própria escola.

O ensino de Língua Portuguesa e de Matemática no país, desde muito tempo atrás, é marcado pelo fracasso escolar dos alunos. Tais disciplinas têm se mostrado incapazes de os fazerem progredir sem maiores dificuldades dentro dos diferentes níveis de ensino. Do mesmo modo, é grande o índice de pessoas escolarizadas que não conseguem mobilizar habilidades de escrita e de leitura para desenvolverem até mesmo atividades mais simples no seu dia-a-dia, como ler e interpretar pequenos textos ou resolverem problemas matemáticos que envolvam simultaneamente duas ou mais operações (INEP, 2004). Essa situação é contraditória por evidenciar que essas disciplinas estão ceifando a motivação inicial do aluno quando este procura ir à escola. Sabe-se hoje que o objetivo da educação escolar é muito mais do que ensinar a ler, a escrever e a contar, todavia, ainda é muito comum ouvir pessoas dizerem inicialmente que vão à escola com esse propósito.

Similarmente ao ensino da língua, o da Matemática é caracterizado, sobretudo, pela reprovação e pelos baixíssimos índices de alfabetismo funcional ${ }^{1}$ dos alunos. É impossível ocultar que existe um problema grave no ensino dessas disciplinas e que, em tais entraves sobressaem-se particularidades com a mesma similaridade, tanto em uma quanto em outra. Face a este pormenor e muitos outros, como o rótulo entreposto a elas, considerando-as como áreas com objetos de estudo situados em pontos opostos, faz desconfiar da veracidade de tais julgamentos e suscita indagações acerca da natureza das dificuldades existentes nos seus ensinos. Portanto, passemos a olhar com menos desconfiança e (pré) conceitos a relação da Língua Portuguesa com a Matemática, até mesmo porque a

\footnotetext{
${ }^{1}$ Conceito que se refere às habilidades em usar a matemática em contextos sociais diversos, sendo muito mais que o conhecimento dos símbolos matemáticos e sua leitura (INEP, 2004).
} 
teoria dos átomos diz que corpos com cargas elétricas opostas se atraem. Se considerarmos a Matemática e a Língua Portuguesa como áreas distintas do conhecimento elas serão mesmo como átomos, partículas mínimas; e se forem ainda, seguindo o raciocínio dessa metáfora, opostas, então, elas podem muito bem caminhar em direção uma da outra e não em sentidos contrários.

1 Matemática e língua materna: sistemas de representação da realidade

De acordo com Lima (apud MACHADO, 2001, p. 76), "Matemática, como o vernáculo, é um instrumento de trabalho intelectual, altamente indispensável na vida". Não é difícil concordar que conhecimentos relativos à Matemática e à língua são indispensáveis à vida moderna. Porém, é difícil compreender porque ambas sendo tão distintas, aparentemente, assumem essa importância. E mais ainda, porque a complexidade e a dificuldade que apresentam nos custam tão caro em sua compreensão. Talvez, parte dessa confusão aconteça pelo conhecimento equivocado que se tem sobre ambas, o que exige um olhar menos superficial distinguindo o que elas são.

De acordo com Machado "a matemática erige-se, desde os primórdios, como um sistema de representação original; apreendê-lo tem o significado de um mapeamento da realidade, como no caso da Língua. [...] concebemos a Matemática como um sistema de representação da realidade, construído de forma gradativa, ao longo da história, tal como são as línguas" (2001, p. 96).

Nas ideias acima se percebe uma visão não platônica da Matemática e da língua, ou seja, Matemática e língua materna como sendo construções humanas e não como objetos com uma existência em um mundo superior. O ser humano ao longo da história da humanidade criou símbolos e construiu saberes com base nessas representações simbólicas e com elas projetou todo conhecimento que possui hoje. Com isso, entender o mundo que nos rodeia carece de uma compreensão dessas estruturas simbólicas, dentre as muitas, a língua e a Matemática.

Segundo Ferreiro, 
no objeto a ser apresentado e uma seleção daqueles elementos $e$ relações que serão retidos na representação. Uma representação $X$ não é igual à realidade $R$ que representa (se assim for, não seria uma representação, mas uma outra instância de R) (2001, p. 10).

Criar um sistema de representação reúne características duais. A primeira delas diz respeito à subordinação do sistema de representação ao homem, haja vista se tratar de algo socialmente construído. Ou seja, um sistema de representação da realidade, como a Matemática e a língua, revela traços da sociedade que a utiliza: uma não neutralidade ou pureza em sua essência. A outra característica está relacionada aos elementos deste representamem, aos símbolos que representarão o objeto e as suas relações nesse sistema. Um sistema de representação se consolida na medida em que símbolos são construídos para exprimirem a visão de alguém focada sobre uma realidade. Desse modo, como diz Machado (2001), esses sistemas de representação são entendidos como sendo uma estrutura capaz de mapear a realidade, não no sentido de construir uma representação à maneira de um protótipo, mas de elaborar um conjunto de símbolos sistematicamente organizados que a expressem. Ou melhor: exprimam uma ideia de alguém em certo momento sobre um fenômeno particular dessa realidade.

A Matemática e a língua são sistemas de representação compostos por signos, na Matemática, os signos formais, na língua, os signos lingüísticos. Ambas possuem um sistema complexo de organização que lhes permitem cumprir suas funções, chamado de gramática, coordenando os seus elementos e coordenando-se de modo a alcançar seus fins. Esse sistema complexo de organização é regulado pela sintaxe, pela semântica e pela pragmática.

\subsection{Língua e signo linguístico: delimitando conceitos e relações}

De acordo com Devlin (2004), a linguagem necessita de uma sintaxe, ou seja, regras regulando o uso dos seus símbolos. É isso que faz com que a linguagem ultrapasse os limites da temporalidade e se firme como ferramenta capaz de comunicar e de fazer compreender uma informação em qualquer local e espaço temporal. 


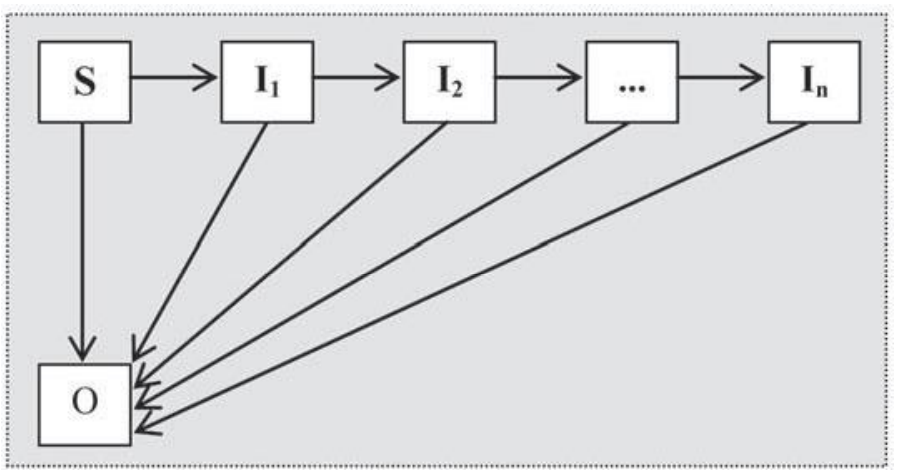

Figura 1: Esquema proposto por Charles Peirce para ilustrar a relação do signo com o objeto e com o interpretante.

Saussure (1987, p. 19) entende que "A língua é um sistema de signos que exprime ideias". Segundo Kristeva (1988, p. 21), "A língua é a parte social da linguagem [...] formada por um sistema de signos em que o essencial é a união do sentido à imagem acústica (som)".

Acreditamos, como Marcuschi (2008), que "a língua é um sistema de práticas com o qual os falantes/ouvintes (escritores/leitores) agem e expressam suas intenções com ações adequadas aos objetivos em cada circunstância" (p. 61). Todavia, tal concepção, pautada em uma visão interativa de linguagem e, portanto, menos formalista, como as proposta por Saussure e Kristeva, ao nosso ver, não exclui a existência de signos em sua estrutura. Tais signos estão organizados segundo regras específicas de combinação criadas pela sociedade.

Uma conceituação de signo nos é dada por Peirce (apud KRISTEVA, 1988, p. 24). Segundo ele, o signo "é aquilo que substitui qualquer coisa para alguém. O signo dirige-se a alguém e evoca para ele um objeto ou um fato na ausência desse objeto e desse fato". Reside no signo linguístico a capacidade de representar a ideia que se tem de um objeto. Essa noção de signo se estabelece em uma relação triádica. O signo é criado para substituir um objeto em situações pontuais de modo que, ao entrar em contato com o signo, um interpretante se remeta diretamente ao objeto nomeado.

Segundo Peirce (Cf. KRISTÉVA, 1988), o signo não se relaciona única e exclusivamente a um interpretante, mas com uma cadeia ilimitada 
deste, haja vista a construção do signo ser regulada por uma convenção social. Um mesmo signo pode evocar objetos diferentes para uma série de interpretantes, o que comprova a não existência de uma estrutura superior denominada pelo signo. O esquema da Figura 1 ilustra a tríade signo - objeto - interpretante.

Segundo Ferreiro (1995), na sua conceituação de sistemas de representação, a construção do signo também não consegue definir um objeto ou um fato em toda a sua essência, todas as suas características. $\mathrm{O}$ que o signo pode revelar é muito dependente da visão do interpretante, que mentaliza apenas alguns dos elementos presentes no objeto representado. Essa ideia do objeto tem estreita relação com a experiência do interpretante, pois, como afirma Granger (1995) "La lengua es essencialmente instrumento de comunicación y el contenido de la comunicación se toma normalmente de lo que llamamos experiencia" (p. 88). Segundo ele, "La associación signo-interpretante, por cualquier processo psicológico que se realice, solo puede ser possible por la comunidad, más o menos imperfecta, de una experiencia entre el locutor y el receptor" (p. 90).

A experiência do interpretante está relacionada à dinamicidade e à riqueza de suas relações com um grupo social, a comunidade falante de sua língua materna. Por outras palavras, a relação de sentidos possível de ser construída por meio da língua se concretiza na relação entre interlocutores em uma situação enunciativa.

2.2 Matemática e linguagem matemática: em busca de uma conceituação

Não existe consenso do que seja realmente a Matemática. A discussão é vasta e generalizada. Para muitos, como Alain Connes, pertencente ao grupo dos defensores da corrente filosófica realista, os objetos matemáticos existem independentemente do homem. "Comparemos a realidade matemática ao mundo material que nos rodeia. O que prova a realidade desse mundo material além da percepção que nosso cérebro tem dele? Principalmente, a coerência do tato e da visão para um só e mesmo indivíduo. A realidade matemática é da mesma natureza" (CHANGEUX; CONNES, 1996, p. 32). 
Em contraste a esse pensamento, outros teóricos afirmam ser o objeto matemático fruto de nossas faculdades cerebrais, construções humanas, sendo a Matemática apenas uma espécie de linguagem, uma linguagem que pretende ser universal. É o que afirma Changeux (CHANGEUX; CONNES, 1996, p. 16): "A matemática é uma linguagem mais rigorosa, nem mais nem menos do que isso".

Para nós, uma definição mais apropriada do conceito de Matemática seria:

Matemática é a classificação e o estudo de todos os padrões
possiveis. A palavra padrão é usada aqui de uma maneira
com a qual nem todos concordarão. Ela deve ser entendida
num sentido bem amplo, cobrindo quase qualquer tipo de
regularidade que se pode imaginar na mente. A vida, e
certamente a vida intelectual, somente é possível porque há
certas regularidades no mundo. Uma ave reconhece as listas
pretas e amarelas de uma vespa; o homem reconhece que o
crescimento de uma planta se segue ao plantio da semente. E,
em cada caso, uma mente está ciente do padrão (SAWYER
apud DEVLIN, 2004, p. 94-95).

Essa definição concorda com a existência de um objeto exterior ao homem, as regularidades, que é percebida pelo nosso cérebro, mas que também é construída por ele. Desse modo, a Matemática não é uma ciência que estuda objetos com existência em um mundo inteligível, apesar desse objeto às vezes depender das impressões obtidas pelos nossos órgãos do sentido. Pelo contrário, ela descreve padrões que podem, ou não, ser encontrados no mundo sensível. Essa característica é conseguida graças à linguagem altamente formalizada dessa ciência, a linguagem matemática.

O status de universalidade atribuído à Matemática se deve em parte ao poder de síntese conferido pela linguagem matemática, ao sentido estrito dos símbolos que compõem a sua linguagem, os signos formais. No exemplo a seguir pode-se visualizar como se processam tais relações no domínio da Matemática, como pode ser pensado um conhecimento matemático. Um dos teoremas do triângulo retângulo pode ser enunciado das seguintes maneiras: 
- Em Língua Portuguesa: "Em todo triângulo retângulo o produto dos catetos é igual ao produto da hipotenusa pela altura".

- Em Linguagem Matemática: " $h a=b c "$.

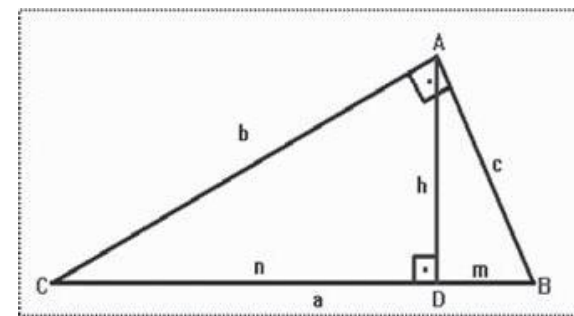

Figura 2 - Triângulo retângulo

Observa-se que tanto a formulação da propriedade em linguagem natural quanto em linguagem matemática tratam do mesmo objeto, traduzem a mesma coisa; o que pode haver, contudo, são dificuldades em maior ou menor grau no processo de compreensão. A diferença entre as duas linguagens é principalmente quanto aos símbolos utilizados. Na linguagem matemática, os signos formais, na língua materna, signos linguísticos. Todavia, vale dizer que as duas linguagens são criações humanas, nenhuma, nem outra preexistiu ao homem como se fosse um cabide em que seus pertences foram cedidos ao ser humano (RIPARDO, 2006).

Portanto, acreditamos que

[...] a matemática constitui uma maneira determinada e específica de interpretar, de observar a realidade. Que usa uma linguagem específica, diferente das linguagens naturais e cuja aquisição não pressupõe a mera 'tradução' para a linguagem natural. E que, portanto, aprender matemática significa aprender a observar a realidade matematicamente, entrar na lógica do pensamento e da linguagem matemática, usando as formas e os significados que thes são próprios (GÓMEZ-GRANELL, 2003, p. 282).

Ou seja, a Matemática é muito mais que a observação simples dos padrões e a sua respectiva transformação em uma linguagem formalizada. A Matemática assim como a língua são recursos que o ser humano utiliza para construir suas relações com o mundo e consigo próprio, numa posição que pode ser tanto de subordinação quanto de imposição.

\section{A simbiose Matemática versus língua materna}

As línguas, em sua maioria do tipo alfabética, possuem sons (representados graficamente pelas letras do alfabeto) que, organizados em 
certas sequências, são capazes de produzirem sentidos (as palavras) para os falantes daquela língua. Já a linguagem matemática possui signos dotados de um sentido universalmente aceito pela maioria das sociedades.

O simbolismo formal matemático, todavia, é dependente de uma formalização linguística de quem o utiliza, de uma interpretação em linguagem natural. Isso deve-se ao fato de inexistirem, nos signos matemáticos, uma oralidade própria, uma entidade simbólica representando uma marca acústica. Isso só é possível por empréstimo da língua do interpretante (MACHADO, 2001; GRANGER, 1995). É por isso que, embora representando o mesmo objeto matemático, uma expressão matemática adequa-se à estrutura morfossintática de cada língua no que concerne a uma tradução linguística (RIPARDO, 2006).

A propriedade fundamental das proporções, por exemplo, assume uma expressão totalmente diferente da língua portuguesa quando representada por outra língua.

- Linguagem matemática: $\quad \frac{a}{b}=\frac{c}{d} \rightarrow b c=a d$.

- Português: Em toda proporção o produto entre os meios é igual ao produto entre os extremos.

- Inglês: In a proportion the product between the means is equal to the product between extremities.

- Espanhol: Em um cociente el producto entre las maneras es igual al producto entre las extremidades.

No exemplo, "ad" não representa a justaposição dos fonemas /a/ e /d/, mas a expressão linguística em português "o produto entre os extremos", ou seja, uma expressão constituída por vários sons que estrutura um significado amplo - o resultado da multiplicação entre o primeiro e o último de uma proporção - apenas com duas letras. Os símbolos sistematizam um conjunto de ideias que também podem ser expressas em uma língua natural.

Essa ausência de uma oralidade própria nos signos da linguagem matemática corresponde ao segundo nível de articulação linguística. Tais signos se consolidam, em termos de representação escrita, sem uma correspondente sonora própria, como define Saussure a respeito do signo 
linguístico: uma marca acústica que remete a um significado. Para que isso aconteça recorre-se à estrutura fonética de uma língua natural.

El sentido de los signos formales unitários [...] no se constituye por remisiones a uma estructura autônoma de oposiciones $y$ de correlaciones correspondiente a uma fonologia. Está directamente acoplado al sistema de los sintagmas que corresponde al primer nivel de articulación de las lenguas naturales. En segundo lugar, el rasgo característico, y hablando con propriedad escandaloso, de esos sistemas simbólicos, es que deliberadamente están construídos de modo de no corresponder a ninguna outra experiencia que la de los mismos símbolos (GRANGER, 1995, p. 93).

De acordo com Martinet, cujo pensamento é comentado por Granger na fala acima, o primeiro nível de articulação em uma língua é o que acontece quando se cria o signo linguístico: atribui-se uma forma vocal (palavra) para o objeto, fenômeno, seres etc. da realidade. A segunda articulação é interna à estrutura da palavra: esta pode ser decomponível em sons, os fonemas. Nos signos da matemática inexistem esse segundo nível. O símbolo =, por exemplo, pega por empréstimo os fonemas $/ \mathrm{i} /, / \mathrm{g} /, / \mathrm{u} / \mathrm{e} / \mathrm{a} / \mathrm{da}$ língua portuguesa e tem sua correspondente sonora /iguau/. Assim, um conhecimento matemático para ser descrito, apreendido ou ensinado a alguém não prescinde do uso da língua, embora possa também ser expresso, independentemente de qualquer língua, em linguagem matemática. Ocorre aí a primeira relação de interdependência da matemática com a língua: a Matemática pega por empréstimo a estrutura fonética da língua para ter uma correspondente sonora para os seus símbolos escritos - icônicos, simbólicos etc.

Davis \& Hersh (apud FONSECA, 1990, p. 11), assim como Granger, chamam atenção para o poder de síntese existente na linguagem matemática. Segundo eles, "[...] sem o processo de abreviatura, o discurso matemático seria quase impossível”.

A Figura 3 exemplifica essa faceta da linguagem matemática. Enquanto a propriedade expressa na língua portuguesa utiliza-se de treze signos verbais com dezoito símbolos escritos (letras) diferentes, em linguagem matemática foram necessárias apenas sete símbolos escritos. 
Estes, contudo, nada dizem isoladamente. Os signos "a", "b", "c", "d" e "=" só são capazes de remeter o interpretante ao significado de um objeto naquela relação apontada por Peirce, porque estão sintaticamente dispostos em um sintagma, em uma sentença matemática.

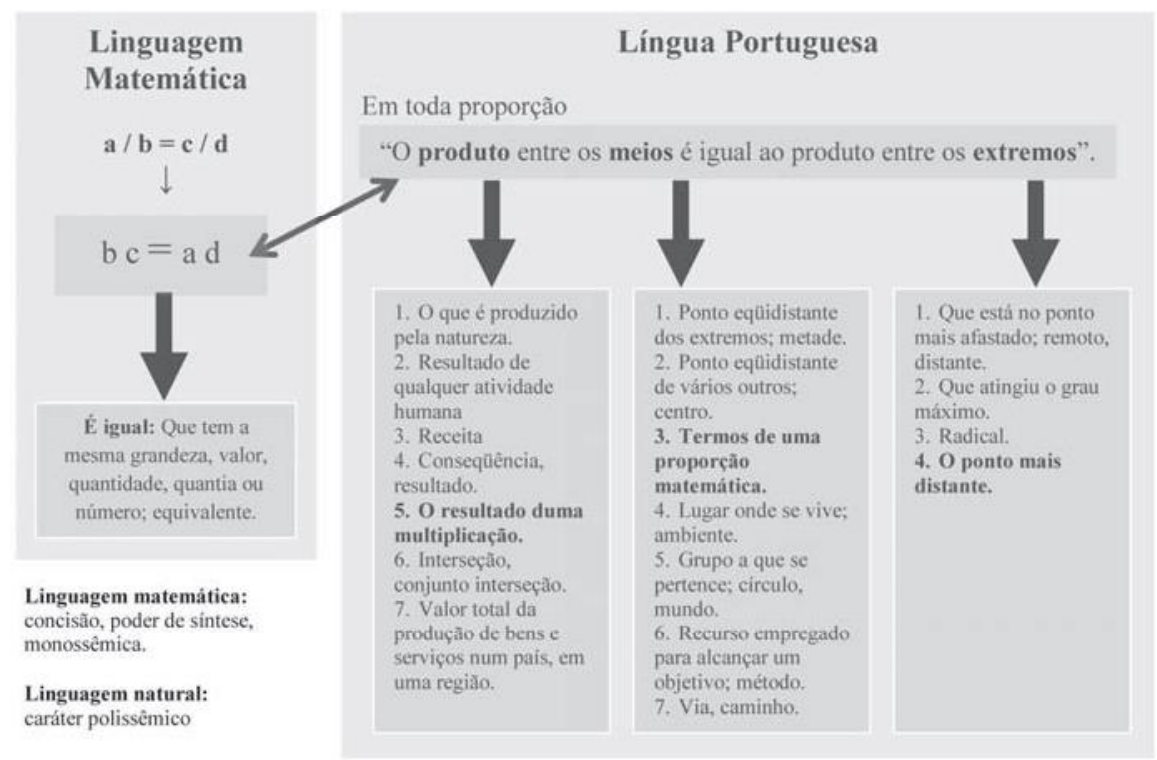

Figura 3: Comparação entre a representação por meio da linguagem matemática e da Língua Portuguesa

Granger (1995) afirma que o discurso matemático não possui um enunciador que não seja a própria sentença, que o interpretante dos símbolos matemáticos é o próprio objeto matemático nomeado por eles, pois este não remete necessariamente a um conteúdo semântico existente em um espaço exterior ao próprio sintagma matemático, como fazem os signos verbais. Nesse caso, não há uma relação com vários interpretantes, mas apenas com um, que é o próprio objeto matemático, os símbolos da linguagem matemática.

Diz ele que a linguagem formalizada da Matemática pode ser reduzida a uma mera estrutura sintática. De fato, como se observa na figura 3, cada signo verbal destacado da Língua Portuguesa possui vários sentidos e somente um deles pode ser aplicado na sentença em questão. Se considerarmos as palavras produto, meios e extremos, cada uma delas com as definições dadas pelo dicionário Aurélio e na sequência em 
que aparecem na frase, desconsiderando-se ainda a utilização de outros conectivos ou a reorganização deles na mesma frase, poderíamos obter aproximadamente duzentos e vinte oito frases diferentes, cada uma com um significado diferente. $\mathrm{Na}$ linguagem matemática o sinal de igualdade tem unicamente um sentido, mas porque está imbricado numa relação com outros símbolos e com regras específicas da álgebra, ao passo que na língua portuguesa cada palavra pode remeter o interpretante a objetos diferentes mesmo não estando em uma sentença verbal.

Passemos à análise mais detalhada da relação estabelecida da língua materna para com a Matemática. Embora na língua um signo possa ser construído sem depender necessariamente da Matemática, esta última lhe dá contribuições significativas que lhe conferem uma roupagem toda especial. Davis \& Hersh (apud FONSECA, 1990, p. 11) salientam que os símbolos notacionais que constituem parte do registro escrito em Matemática são "um acréscimo numeroso e exuberante aos símbolos das linguagens naturais". De acordo com eles, desde cedo, a criança convive com esses símbolos e aprende a manuseá-los e, com o passar do tempo, e à medida que progride de uma série para outra na escola, incorpora novos em seu conjunto de conhecimentos. Esse aprendizado acontece tanto por meio do contato visual com o símbolo escrito quanto por meio do contato com o nome destes, ou seja, via oralidade.

Wittgenstein (1996), com a sua teoria dos jogos de linguagem, acrescenta a exemplificação de como isso acontece. Segundo ele, é só no seio de uma práxis específica que determinada palavra adquire sentido, sendo a práxis da linguagem entendida por ele como um jogo de linguagem:

Na práxis do uso da linguagem (2), um parceiro enuncia as palavras, o outro age de acordo com elas; na lição de linguagem, porém, encontrar-se-á "este" processo: o que aprende "denomina" os objetos. Isto é, fala a palavra [...] Podemos também imaginar que todo o processo do uso das palavras em (2) é um daqueles jogos por meio dos quais as crianças aprendem sua língua materna. Chamarei esses jogos de jogos de linguagem", e falarei muitas vezes de uma linguagem primitiva como um jogo de linguagem. [...] Chamarei também de "jogos de linguagem" o conjunto da linguagem e das atividades com as quais está interligada (WITTGENSTEIN, 1996, p. 29-30).

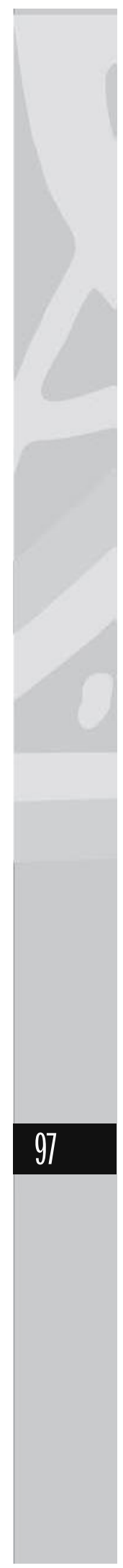


A teoria dos jogos de linguagem é entendida como uma atividade humana, como atividades sociais construídas pelo homem. Dessa forma, o uso das palavras, o comportamento, as ações conjuntas, a gesticulação, a interação verbal etc. é o que torna possível o uso efetivo da linguagem. A língua materna é aprendida por uma criança a partir do momento que ela vivencia, pratica os jogos de linguagem, como numa brincadeira de roda. É essa interação que lhe permite fazer uso da língua e, mais tarde, praticar outros jogos de linguagem, como a Matemática.

O uso contextual que se faz da língua, aprendendo a selecionar as palavras e expressões adequadas em determinadas situações, desenvolve as habilidades para se jogar também com a Matemática, aprimorando o senso e a capacidade numéricos. A Matemática é um jogo de linguagem, pois seus conhecimentos e procedimentos são determinados por formas de vida, atitudes sociais.

Para Wittgenstein (1996, p. 43), "Pode-se, para uma grande classe de casos de utilização da palavra 'significação' - se não para todos os casos de sua utilização -, explicá-la assim: a significação de uma palavra é seu uso na linguagem”. A Matemática e a Língua Portuguesa possuem suas estruturas próprias para representarem a realidade e, mesmo a linguagem matemática não se utilizando primariamente de palavras em suas representações, os signos matemáticos podem ser traduzidos por palavras do português.

É exatamente nesse ponto que a Matemática vem dar uma contribuição ímpar para o Português. Machado (2001) chama a atenção para o fato de que a linguagem ordinária e a Matemática se utilizam de termos anfíbios, ou seja, que designam conhecimentos tanto da Matemática quanto da língua.

Assim como na situação da Figura 4, no uso diário de nossas falas, em nosso discurso, é comum a troca de termos entre essas duas áreas. $\mathrm{Na}$ folha de classificados de um jornal, por exemplo, encontrar-seá a representação "R $\$ 8,00$ " ao invés de "oito reais". Do mesmo modo costumamos empregar termos matemáticos em expressões da língua, como é o caso do termo "quarto" para nomear um cômodo da casa que, geralmente, corresponde a $1 / 4$ desta (RIPARDO, 2006). 

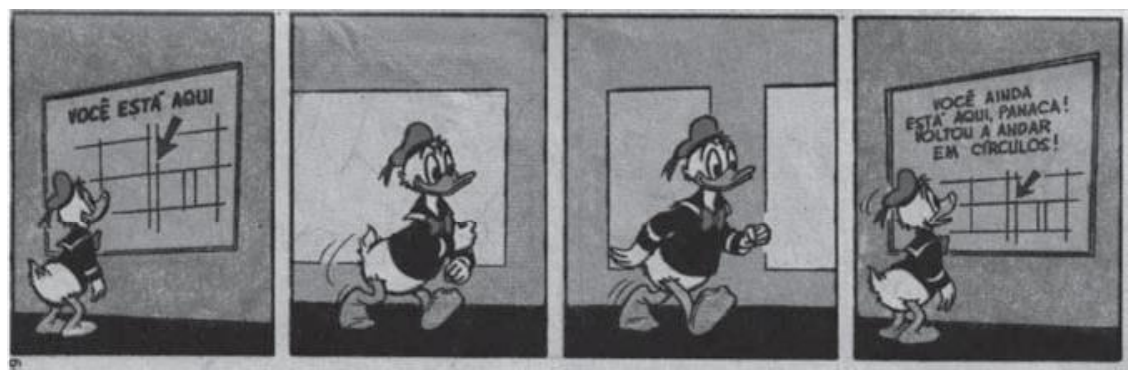

Figura 5: DISNEY, Walt. Piadinhas do Donald. In: Alamanaque Disney. Editora Globo. № 231.

Essa riqueza conferida à língua é possível devido ao poder de recriação existente na metáfora, que é a substituição de um termo por outro ou por uma expressão equivalente por causa de uma relação de semelhança entre ambos. Essa troca se realiza em um momento de uso de nossa língua, em uma situação da linguagem, em uma circunstância específica, ou seja, no seio de uma prática, na práxis de um jogo de linguagem. Portanto,

A metáfora tem a ver com a semântica da frase, antes de dizer respeito à semântica de uma palavra. E, visto que uma metáfora sófaz sentido numa enunciação, ela é um fenômeno de predicação, não de denominação [...] E só o conjunto constitui a metáfora. Assim, não deveríamos efectivamente falar do uso metafórico de uma palavra, mas antes de enunciação metafórica. A metáfora é o resultado da tensão entre dois termos da enunciação metafórica (RICOUER, 1976, p. 61).

Para que o novo significado possa emergir é necessário que se abandone o sentido literal da palavra. A redescrição do fenômeno por meio da construção metafórica se faz por meio de um processo cognitivo e emocional que é também parte da função heurística. O vácuo existente entre os dois termos, o da matemática - círculo - e o da língua portuguesa - perdido -, se dispersa a partir da aproximação dos campos semânticos estabelecidos em torno de tais palavras quando elas são tiradas da exclusividade de suas respectivas áreas de atuação. Ou melhor, quando rompem com o casulo da sintaxe da linguagem matemática e da Língua Portuguesa e constroem uma semântica. 
$\mathrm{Na}$ tirinha foi feita uma transferência analógica de sentidos que se configurou em novo significado. A palavra círculos é usada como sinônimo de perdido. O termo círculo é primeiramente fornecido à Matemática pela Língua Portuguesa para nomear um padrão - a reunião da circunferência com a área interna da região delimitada pela circunferência -, em seguida, retorna ao português emprestado pela Matemática - usado como advérbio -, para significar uma situação em que alguém não consegue encontrar o local que deseja, um caminho a seguir. A substituição do termo está perdido por andar em círculos não foi uma escolha aleatória. Ela cumpre um papel preponderante na composição final do significado do enunciado, pois sua força retórica produz um efeito especial para o leitor e, consequentemente, para o produtor da revista (RIPARDO, 2006). É o que afirmam Wittgenstein (1996), quando diz que é na prática que a significação de uma palavra se estrutura, e Ricouer ao visualizar que:

[...] uma metáfora memorável tem o poder de reunir dois domínios [a heurística e redescrição] separados numa relação cognitiva e emocional, utilizando a linguagem directamente apropriada para um como uma lente para ver o outro". [...] Assim como o sentido literal se tem de abandonar para que o sentido metafórico possa emergir, assim também a referencia literal deve desaparecer para que a função heurística possa operar a sua redescrição da realidade (RICOUER, 1976, p. 79).

Constantemente utilizamos enunciados metafóricos com termos matemáticos como esse e nem nos damos conta disso. Certamente não estamos pensando em uma fração, quando dissemos que algo aconteceu numa "fração de segundos", ou que "sair pela tangente" não se refere a uma circunferência e a uma reta tangente a ela. Dizer que no Brasil os pobres ocupam a base de nossa "pirâmide social", logicamente, não faz uma alusão direta ao conceito de pirâmide no contexto delimitado pela Matemática, contudo, guarda estreita relação de sentido com o sólido geométrico cuja base tem maior capacidade de armazenagem do que seu ápice. Metáforas como essas evidenciam o quanto, em nossa prática, há de Matemática em simbiose com a nossa língua materna, com a Língua Portuguesa. 


\section{Mais do que simples instrumentos de expressão e comunicação}

Matemática e línguas naturais estão, de acordo com Devlin (2004), assentadas na capacidade humana inata para a linguagem. Portanto, pensar na Matemática e na Língua Portuguesa é voltar-se para a compreensão do fenômeno da linguagem.

Durante algum tempo, e ainda na atualidade, foi muito acirrada a discussão sobre ser a função primária da linguagem a expressão ou a comunicação do pensamento. Abramovich, apoiado nas concepções de Wittgenstein sobre linguagem, diz que:

[...] a função das expressões lingüísticas não pode estar assentada exclusivamente em sua relação representativa para com o mundo, mas, pelo contrário, que elas têm uma ampla variedade de funçóes diferentes, de tal modo que seria um erro sério supor que estas funções poderiam ser reduzidas a uma forma única (1999, p. 20 - grifo nosso).

O próprio Wittgenstein salienta que devemos

[...] promover uma ruptura radical com a idéia de que a linguagem sempre funciona de uma só maneira e está sempre a serviço do mesmo objetivo - comunicar pensamentos, que podem ser a respeito de casas, dores, o bem e o mal, ou o que quer que seja [grifo nosso] (1996, p. 109).

Defato,ébastante reducionistaaideiadequerersimplificarasfunções de uma expressão linguística a mera função expressiva ou comunicativa, sobrepondo a prioridade da existência de uma em relação à outra e viceversa. Como afirma Machado (2001), comunicação e expressão são sem sombra de dúvida, um amálgama do poder de representação da língua, mas a língua também desempenha outros papéis como os de interpretar, produzir significados, criar, compreender, extrapolar. Do mesmo modo, Bagno (2007) e Couto (1994) afirmam que com a língua se pode dominar, subjugar, ou seja, pode ser um instrumento de poder e dominação que, dentre outras formas, se exerce pelo preconceito linguístico. 
A linguagem matemática também pode servir a outras funções que não sejam somente expressar uma ideia ou um conceito matemático, como se poderia pensar, ou ainda estabelecer-se como um mecanismo sólido de comunicação entre pensamento matemático e realidade. Determinadas sentenças matemáticas podem servir muito mais como ferramenta para inibir o aprendizado por parte do aluno ou para imprimir-lhe o sentimento de inferioridade do que para impulsionar-lhe na construção de um novo conhecimento. Essa mesma linguagem usada por diversas outras ciências e campos do conhecimento, para traduzir em expressões particulares determinado saber pode reforçar ao que Araújo (2007) chama de ideologia da certeza em matemática ${ }^{2}$, pode reforçar o preconceito e as desigualdades sociais.

Granger também afirma que:

Pero que hecho la complejidad de las expresiones formales llega a ser rápidamente tan exorbitante, que excede las possibilidades de memorización y de sintesis de uma mente común; lo que se gana en rigor, se pierde radicalmente en eficacia. De tal modo que el objetivo de las construcciones estrictamente formalizadas no es tanto utilizarlas como médios de comunicación como probar la possibilidad de su utilización y garantizar asi "abusos de lenguaje" del discurso científico, como ocorre constantemente en matemáticas (1995, p. 92).

Queremos deixar claro, portanto, que expressões da linguagem, quer sejam em Matemática ou na língua materna, não podem ser visionadas apenas sobre o aspecto da expressão e comunicação. Embora estes se destaquem como um dos principais, as expressões também cumprem com outros papéis que têm reflexos atenuadores na sociedade.

A Matemática constrói seus objetos utilizando simultaneamente uma língua materna com a linguagem matemática. A partir disso é que a formalização desse conceito adquire representações autônomas tanto em uma forma de linguagem quanto em outra. Os objetos matemáticos, então,

${ }^{2}$ A ideologia da certeza sustenta uma visão da Matemática que atribui a ela o poder de detentora do argumento definitivo em qualquer debate na sociedade, dentre eles, o político. 
nomeados por termos em língua materna, são usados livremente pela comunidade de matemáticos e, posteriormente, pelos "não matemáticos", se relacionando com conhecimentos construídos e possibilitando a construção de novos outros.

En realidad este uso permanece virtual. Todo matemático utiliza la lengua matematica, en simbiosis con su lengua natural, dotando a los símbolos de significaciones más o menos cargadas, porque es capaz de vivir, hasta cierto punto, uma experiencia matemática (GRANGER, 1995, p. 94).

A Matemática possui um veículo próprio para expressar seu objeto de estudo - a linguagem matemática. Por ser uma linguagem praticamente autônoma esta aí grande parte da estrutura que confere à Matemática o título de ciência. Contudo, apesar de se apregoarem por aí uma independência da Matemática das outras ciências, haja vista essa particularidade, tal linguagem só é autônoma em termos de representação escrita dos seus códigos. No campo da oralidade, a linguagem matemática carece totalmente de uma tradução linguística por parte de uma língua materna, o que torna a Matemática tão dependente da língua quanto as outras ciências.

Se, separadamente, e ao seu modo, na escola, Matemática e Língua Portuguesa são usadas mais para reprovar e reafirmar as desigualdades sociais do que para propiciar ao aluno parte das ferramentas necessárias para os fazerem tirar proveito delas e se lançarem no desenvolvimento e no conhecimento ao longo da vida, juntas elas têm poder redobrado, tanto para alcançar um objetivo quanto para o outro.

No último quadrinho da Figura 4, esse poder fica mais evidente. No texto predomina a função conativa ${ }^{3}$ da linguagem, ou seja, visa a influenciar o comportamento do receptor da mensagem. Além de informar que o personagem encontra-se perdido, tenta persuadi-lo de que não é capaz, ou não foi, ou não usou suas habilidades cognitivas para ler e entender a mensagem do cartaz anterior, orientar seu percurso no

\footnotetext{
${ }^{3}$ Classificação dada pelo linguista Roman Jackobson, de acordo com o objetivo principal
} pretendido em uma enunciação.

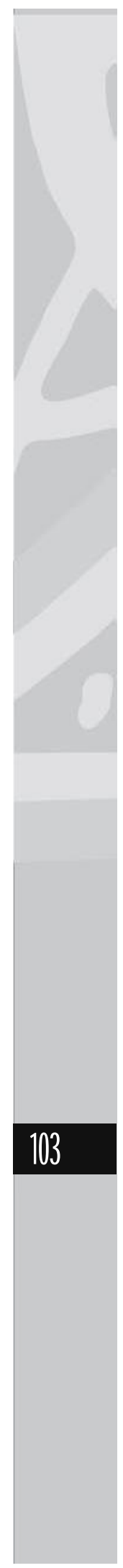


local e chegar ao destino desejado. Em outras palavras, está chamando o Donald de "burro", imbecil, idiota. Para imprimir na personagem essa conclusão, foi usado na segunda oração o termo círculos. Ou seja, buscou auxílio de um termo matemático familiar no uso diário em nossos atos de comunicação mesclado com uma figura de linguagem para cumprir um papel bem diferente (RIPARDO, 2006).

Portanto, passemos a olhar com menos superficialidade o ensino e o uso da Língua portuguesa e da Matemática, nas nossas práticas diárias, envolvendo-as. Longe de serem meras ferramentas de expressão e comunicação do pensamento, estas podem ser usadas como instrumentos de poder e dominação, mas também podem ser o impulso do trampolim necessário para alcançar a emancipação pessoal e social.

\section{À guisa de conclusão}

Os dois temas tratados neste artigo mostraram que, ao contrário do que é popularmente disseminado, são duas estruturas do conhecimento humano cujas características e funções possuem as mesmas raízes epistemológicas. Matemática e língua materna são sistemas de representação pelos quais o ser humano interrelacionase consigo mesmo, com os outros e com mundo. Pela importância que assumem em nossas vidas, não dá para ignorar o desdobramento negativo que ideias equivocadas, construídas principalmente dentro do ambiente escolar sobre elas, podem assumir. Embora assentadas em modos particulares de representar, ambas são fruto da capacidade humana para a linguagem.

Ao invés de tornar a Matemática um sistema de signos débil e limitado, as ideias matemáticas, expressas pela linguagem matemática versatiliza o conhecimento matemático devido à estruturação sintática dos signos nesse sistema. O rigor formal e a abstração dos seus signos possibilitam uma estruturação sintática capaz de produzir significados internamente sem a necessidade de um contexto prévio orientando essas relações. A sintaxe matemática constrói um campo semântico em si mesma, com regras autônomas, sem obrigatoriamente vincular-se a uma situação previamente determinada. Contudo, apesar de essa estrutura ser 
fechada, sua gramática não inviabiliza a aplicação desse conhecimento a contextos reais, não rompe com as chances de haver um pragmatismo nas expressões matemáticas, como é o caso das metáforas com termos matemáticos muito utilizados pelos falantes da Língua Portuguesa (RIPARDO, 2006).

Com relação à Língua Portuguesa, esta se configura como outro sistema de representação altamente eficaz. O seu poder de moldar estruturas propícias à construção do conhecimento é tão abrangente que abarca a Matemática, uma ciência cercada de mitos, ao longo de sua história, e, de modo análogo, perpetua, ao longo do tempo, os mesmos problemas com relação ao seu ensino, consolidando ainda mais o círculo vicioso do preconceito linguístico e acentuando as diferenças sociais.

Como força retórica, com poder de redescrição e descoberta, a metáfora é um tropo que serve para ilustrar muito bem a relação de interdependência mútua da Língua Portuguesa com a Matemática (MACHADO, 2001).

Tendo em vista que nossa sociedade estabelece inúmeras formas de exercer poder e exploração sobre as pessoas, é razoável pensar que a apatia existente quanto ao aprendizado da língua e da Matemática não sejam assim tão casuais. "A linguagem não tem nada de trivial. Nós somos essencialmente seres que utilizam linguagem. Nossa linguagem e as formas de nossa linguagem moldam nossa natureza, dão forma ao nosso pensamento, preenchem nossa vida" (HACKER, 2000, p. 16). Refletir sobre os problemas que afetam a ambas é um caminho a percorrer na tentativa de diminuir falsas conjecturas que as permeiam. A discussão está posta e precisa com urgência agendar pesquisas na área.

\section{REFERÊNCIAS}

ABRAMOVICH, L.S. Ludwig Wittgenstein e a Teoria da Literatura. Porto Alegre: EDIPUCRS, 1999. (Filosofia, n. 88).

ARAÚJO, J. L. de. Relação entre matemática e realidade em algumas perspectivas de Modelagem Matemática na Educação Matemática. In: BARBOSA, J. C.; CALDEIRA, A. D.; ARAÚJO, J. L. (Org.). Modelagem Matemática na Educação Matemática Brasileira: 
pesquisas e práticas educacionais. Recife: SBEM, 2007. (Biblioteca do Educador Matemático, V. 3).

BAGNO, M. Preconceito Lingüístico: o que é e como se faz. $48^{\mathrm{a}}$ ed. São Paulo: Edições Loyola, 2007.

CHANGEUX, J. P.; CONNES, A. Matéria e Pensamento. Tradução de Luiz Paulo Roanet. São Paulo: Editora da Universidade Estadual Paulista, 1996. (Biblioteca Básica).

CONDÉ, M. L. L. Wittgenstein: linguagem e mundo. São Paulo: Annablume, 1998.

COUTO, H. H. do. O que é Português Brasileiro? $8^{a}$ ed. São Paulo: Brasiliense, 1994. (Primeiros Passos, v. 164).

DEVLIN, K. J. O Gene da Matemática. Rio de Janeiro: Record, 2004.

FERREIRO, E. Reflexões sobre Alfabetização. 24a ed. São Paulo: Cortez, 1995. (Questões da Nossa Época, v. 14).

FONSECA, M. C. F. R. O simbolismo em Matemática: uma tentativa do resgate do seu caráter educativo. In: Bolema, ano 5, n. 6. Rio Claro: UNESP, 1990.

GÓMEZ-GRANELL, C. A aquisição da linguagem matemática: símbolo e significado. In: TEBEROSKY, A.; TOLCHINSKY, A. Além da alfabetização: a aprendizagem fonológica, ortográfica, textual e matemática. São Paulo: Editora Ática, 2003. p. 257-282.

GRANGER, G-G. Objeto, estructuras y significaciones. In: Estructuralismo y Epistemologia. Buenos Aires: Ediciones Nueva Visión, 1970. p. 77-121.

INEP - Instituto Nacional de Estudos e Pesquisa Educacionais Anísio Teixeira. SAEB - 2005. Resultados do $4^{\circ}$ INAF / Brasil: um diagnóstico para a inclusão social pela educação (Habilidades Matemáticas). São Paulo: 2004. Disponível em: < http://www.ipm.org.br/ipmb_pagina.php? $\mathrm{mpg}=4.02 .00 .00 .00 \& \mathrm{ver}=$ por $>$. Acesso em: 30/08/2008.

KRISTEVA, J. História da Linguagem. Lisboa: Edições 70, 1988.

LYONS, J. Linguagem e Lingüística: uma introdução. Rio de Janeiro: Guanabara, 1987.

MACHADO, N. J. Matemática e Língua Materna: análise de uma impregnação mútua. $5^{\text {a }}$ ed. São Paulo: Cortez, 2001.

MARCUSCHI, L. A. Produção textual, análise de gêneros e compreensão. São Paulo: Parábola Editorial, 2008. 
RICOUER, P. Teoria da interpretação: o discurso e o excesso de significação. Lisboa: Edições 70, 1976.

RIPARDO, R. B. Língua portuguesa e matemática: reduzindo a um denominador comum. Trabalho de Conclusão de Curso Campus Universitário de Altamira/UFPA, 2006.

SAUSSURE, F. Curso de Lingüística Geral. 13 ${ }^{\text {a }}$ Ed. São Paulo: Cultrix, 1987.

WITTGENSTEIN, L. Investigações filosóficas. Trad. de José Carlos Bruni. São Paulo: Nova Cultural, 1996. (Os Pensadores). 